\title{
Reproducibility of strain and twist measurements calculated using CSPAMM tagging
}

\author{
Peter Swoboda ${ }^{1 *}$, Abdulghani Larghat ${ }^{2}$, John Greenwood ${ }^{2}$, Sven Plein ${ }^{2}$ \\ From 2011 SCMR/Euro CMR Joint Scientific Sessions \\ Nice, France. 3-6 February 2011
}

\section{Objective}

To establish inter-observer and inter-study variability of CSPAMM (complementary spatial modulation of magnetization) tagged CMR data.

\section{Background}

The reproducibility of CSPAMM-derived myocardial strain and left ventricular twist have not been described in detail.

\section{Methods}

12 healthy volunteers ( 6 males, mean age $33 \pm 7$ years) underwent CMR studies on a $1.5 \mathrm{~T}$ system (Intera CV, Philips Healthcare, The Netherlands). Tagged CMR images were acquired at the apex, mid-ventricle and base with a CSPAMM pulse sequence (field of view: $300 \mathrm{~mm}$, matrix $128 \times 128$, slice thickness $10 \mathrm{~mm}$, tag separation $8 \mathrm{~mm}, 18$ phases, typical TR/TE $30 \mathrm{~ms} / 6 \mathrm{~ms}$, flip angle 25 degrees). In 6 volunteers repeat data sets were acquired after a mean interval of $8 \pm 3$ days.

Data were analysed by two independent observers using Tagtrack software (Gyrotools, $\mathrm{CH}$ ). Circumferential Langranian strain, radial Langranian strain and rotation were calculated for the three short axis slices. Endocardial and epicardial borders were drawn, and a midline calculated automatically. Left ventricular twist was calculated by subtracting the basal rotation from the apical rotation. The mean difference between paired measurements, the standard deviation (SD) of the differences and the coefficient of variability $(\mathrm{Co}-\mathrm{V})$ were calculated.

\section{Results}

Circumferential strain increased from base to apex (Figure 1a). Mean (SD) difference in circumferential

Leeds General Infirmary, Leeds, UK

Full list of author information is available at the end of the article strain between the two operators was 6.9\% (2.3), 8.2\% (7.7) and $6.7 \%(5.0)$ at apex, mid-LV and base respectively. There was no significant difference in inter-observer variability in endocardial, midline and epicardial contours. See Table 1 for Co-V results.

Mean (SD) difference in mid-myocardium circumferential strain between visits was $6.7 \%(4.1), 6.5 \%$ (4.0) and $8.8 \%(5.2)$ at apex, mid-LV and base respectively.

Mean (SD) difference in radial strain between operators was $28.1 \%$ (47.8), $17.6 \%$ (21.6) and $26.7 \%$ (25.6) and

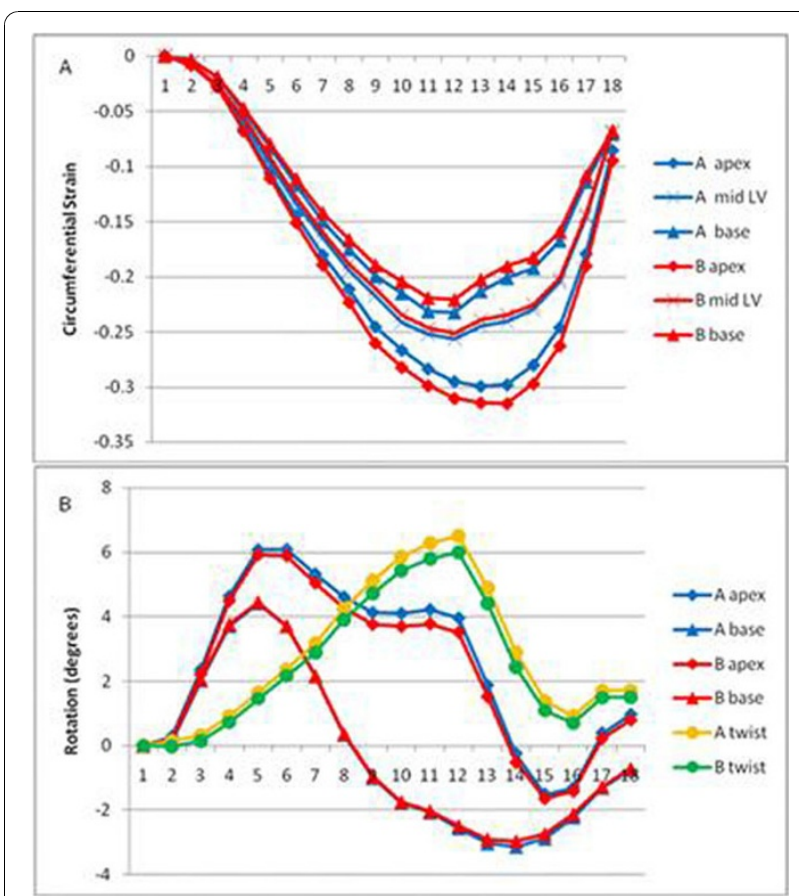

Figure 1 Figure 1a shows circumferential strain measured by observers A \& B. Figure $1 \mathrm{~b}$ shows rotation measured by observers $A$ $\& B$ and calculated left ventricular twist. 
Table 1 shows percentage difference and coefficient of variation (Co-V) for inter-observer and inter-study variability of measured circumferential strain, radial strain and left ventricular twist

\begin{tabular}{|c|c|c|c|c|c|}
\hline & & \multicolumn{2}{|c|}{$\begin{array}{l}\text { INTER-OBSERVER } \\
\text { VARIABILITY }\end{array}$} & \multicolumn{2}{|l|}{$\begin{array}{l}\text { INTER-STUDY } \\
\text { VARIABILITY }\end{array}$} \\
\hline & & $\begin{array}{l}\text { Percentage } \\
\text { difference } \\
\text { (mean (SD)) }\end{array}$ & $\begin{array}{l}\text { Co- } \\
\text { V \% }\end{array}$ & $\begin{array}{l}\text { Percentage } \\
\text { difference } \\
\text { (mean (SD)) }\end{array}$ & $\begin{array}{l}\text { Co- } \\
\text { V \% }\end{array}$ \\
\hline $\begin{array}{l}\text { circumferential } \\
\text { strain }\end{array}$ & apex & $6.9(2.3)$ & 4.4 & $6.7(4.1)$ & 8.3 \\
\hline $\begin{array}{l}\text { circumferential } \\
\text { strain }\end{array}$ & $\begin{array}{l}\text { mid } \\
\text { LV }\end{array}$ & $8.2(7.7)$ & 11.2 & $6.5(4.0)$ & 7.7 \\
\hline $\begin{array}{l}\text { circumferential } \\
\text { strain }\end{array}$ & base & $6.7(5.0)$ & 6.8 & $8.8(5.3)$ & 10.8 \\
\hline radial strain & apex & $28.1(47.8)$ & 19.2 & $7.3(6.0)$ & 9.0 \\
\hline radial strain & $\begin{array}{l}\text { mid } \\
\text { LV }\end{array}$ & $17.6(21.6)$ & 18.2 & $21.3(11.1)$ & 30.8 \\
\hline radial strain & base & 26.7 (25.6) & 42.1 & $35.6(29.6)$ & 59.2 \\
\hline rotation (twist) & $\begin{array}{l}\text { apex- } \\
\text { base }\end{array}$ & $5.7(4.3)$ & 4.0 & $12.3(9.9)$ & 59.2 \\
\hline
\end{tabular}

between visits was $7.3 \%(6.0), 21.3 \%(11.0)$ and $35.6 \%$ (29.6) at apex, mid-LV and base respectively.

The mean (SD) difference in mid-myocardium left ventricular twist between operators was $0.6^{\circ}\left(0.3^{\circ}\right)$ or $5.7 \%(4.3)$ and between visits was $1.2^{\circ}\left(\mathrm{SD} 0.9^{\circ}\right)$ or $12.3 \%(9.9)$.

\section{Conclusions}

The inter-observer and inter-study variability of circumferential strain and LV twist measured from CSPAMM tagged CMR data are low, but are higher for radial strain.

\section{Author details}

'Leeds General Infirmary, Leeds, UK. ${ }^{2}$ University of Leeds, Leeds, UK.

Published: 2 February 2011

Cite this article as: Swoboda et al: Reproducibility of strain and twist measurements calculated using CSPAMM tagging. Journal of Cardiovascular Magnetic Resonance 2011 13(Suppl 1):P52.

Submit your next manuscript to BioMed Central and take full advantage of:

- Convenient online submission

- Thorough peer review

- No space constraints or color figure charges

- Immediate publication on acceptance

- Inclusion in PubMed, CAS, Scopus and Google Scholar

- Research which is freely available for redistribution

Submit your manuscript at www.biomedcentral.com/submit
C Biomed Central 